\title{
Artistic Production in the Bamum Kindom: An Economically Oriented Ideological Hybridization
}

\section{Authors: Mama Moustapha Nchourupouo Mfouapon; Ismaïla Datidjo}

\author{
University of Bamenda - Cameroon; University of Dschang - Cameroon. \\ nchourupouomoust@yahoo.com; datidjojunior@yahoo.fr
}

DOI: 10.26821/IJSRC.9.6.2021.9607

\begin{abstract}
Studies on technical systems in Africa show that art is a category of material culture in the broadest sense and is of prime importance. This is due to a predominantly exotic ethnographic literature and to the influence of a Western-centred representation of African art. An imported model increasingly dominates the perception of African works of art. This means that the artistic productions of modern Africa are rather the reflection of endogenous genius turned towards the satisfaction of exogenous/aspirations. In this vein, as a centre of production and dissemination of works of art, the bamum land reflects the immersion of African artists in a movement of original artistic productions. Consequently, art becomes a springboardfor the improvement of the living conditions of the population and therefore the development of its production centre. In this respect, Foumban, which stands out as a very active centrein the production and marketing of so-called "African art" objects, principally meant for tourists, will offer a framework for this

study. Through a qualitative and quantitative approach by means of guided interviews and direct observations, this article draws its inspiration from the owners of art factories and a private collection in Foumban.
\end{abstract}

Keywords: material culture, industrialisation of art, court art, hybrid art, disethnicisation.

\section{Introduction}

Because of its long-standing artistic tradition, the bamum land in general and its main city, Foumban, in particular, is obviously a region whose cultural heritage of a material nature is an attraction both for tourists eager to discover it and for anthropologists and other humanities researchers. Thanks to its age-old contact with other cultures, especially the western culture, mainly tourists, the perception, design and production of artefacts in this society witnessed and is still witnessing profound changes. In many cases, the art work lost much of its utilitarian connotations of yesteryear and now assumes a meaning quite different from that bequeathed by ancestors to succeeding generations. Based on data collected during qualitative and quantitative surveys carried out with a sample of about twenty actors in the artistic sector in Foumban, this article questions the current status of works of art production in this community in a bid to demonstrate that the sector is becoming industrialized and is in full expansion. We will endeavour to highlight the artistic dynamics in this area, making sure we distinguish 
Volume 9 Issue 6 June 2021

between the neo-traditional objects currently in vogue and the authentic traditional objects. We will also review the various technical systems and other local materials that are used extensively or exclusively as evidenced in a private collection in Foumban.

\section{Problematics}

From the outset, it should be noted that all works of the mind in traditional Africa carried a utilitarian load, and for some, a religious value that gave them a sacred dimension within the societies that produced them. These characteristics of local material culture objects are nowadays integrated into the artistic repertoire, thus building a bridge between ethnography and art through an essentially exotic literature. While Africa is gradually recovering from the plundering of its material productions orchestrated at the time of colonisation by westerners who saw them as objects of delight, the market for so-called contemporary african art has been developing over the past few decades owing to collections by public and private buyers, of western origin in fact. These buyers are increasingly attracted to these objects to the point of drawing the attention of holders of production workshops and sellers of these art objects to their interest. This suggests a form of cultural exchange between the North and the South. The bamum kingdom is not left out of these exchanges, whereby thousands of art objects are produced and sold each year to mostly foreign buyers and consumers.

A close look at the local production and distribution circuit as well as the external consumption circuit leads to certain observations. The objects now produced by local workshops and sold directly to expatriates or indirectly through local art dealers reflect the desire of artists and craftsmen to provide buyers with attractive products that can be sold more quickly and in greater quantities, as they reflect the expectations of the target audiences. We are therefore witnessing the design and production in "industrial" quantities of works of art meant for delight and simulating traditional objects with a utilitarian purpose, whether religious or not. The fact remains that these new objects, devoid of any sacred value or functional significance, are only intended for sale in order to be formally appreciated. This testifies to the paradox that works of the mind, i.e. contemporary african art objects, far from being basically a continuation of the tradition of their forefathers, are commercial products intended to be transferred for other purposes that break with the black african tradition.

\section{Methodology}

As a methodological approach adopted in this article, we felt it necessary to move away from the dominant idea of a certain period, which presented african ethnic groups as static entities. This is despite the mutation created by colonisation. This ethnological approach, tinged with ideology to say the least, is questionable insofar as it exempts the peoples of Africa as well as their material productions from any form of change. Thus, far from considering with nostalgia the near or distant past of these peoples or regretting in some way that they have not remained frozen like vulgar canned vegetables, it is obvious that, like any other human society, these cultural universes are in constant movement; this was the case long before the influences due to colonisation, which only accelerated the development process in a new perspective. In the field of art, or more precisely in the study of technical systems and material culture, it is important to consider Africa in its current specificity, because it is altered and is now a two-headed continent: it is the object of a western experience called "modern" and of its own experience called "traditional". It is in this vein that we decided to adopt both a synchronic and diachronic 
Volume 9 Issue 6 June 2021

approach. This justifies the fact that allusions are made in turn to traditional material culture as well as to the "neo-traditional art" that was unleashed between the end of the 19th and the beginning of the 20th century.

\section{Brief overview of the art production activity of the Bamum}

The production activity that used to be concentrated around the palace and in Njiyouom, the main handicraft neighbourhood in Foumban, now tends to spread across the town and even to many other surrounding villages. We are thus witnessing a proliferation of workshops that reflect the real craze that this activity arouses among the population. Thus, there is nothing uncommon to find more than a dozen workshops within a radius of 200 metres. This phenomenon, which was hitherto observable in Njiyouom, is now visible in the Njinka, Manka, Kounga, Fontain, Njindare, Mambain neighbourhoods, to name a few, and across the town. The Manka neighbourhood is specialised in the production of woodcarving and has the reputation of having contributed to the training of most woodcarvers in the kingdom. Some of them have nowadays set up their own businesses, often around their family compound. This led to a growing trend towards self-employment, as well as to the proliferation of workshops and the massive involvement of actors in this sector, which is becoming increasingly liberalized and more in touch with other layers of the population than ever before.

Furthermore, due to the scarcity in Foumban of plant species used as raw material, some woodcarvers have decided to move to rural areas where wood is still sufficiently available. They settle there to carry out a greater part of their work on the spot. This urban exodus facilitates the involvement of some peasants in this activity, which recruits in both urban and rural areas. This phenomenon, which enables the transfer of technology to rural areas, is often at the initiative of artists from these villages living in Foumban.

\section{Role of Bamum traditional authorities in promoting artistic activity}

The reign of the eleventh king, Мьоиотьоио, marks the birth of a "court art" among theBamum. Its blossoming dates back to the 18th century with this king who distinguished himself by numerous warsat the end of which the Bamum conquered many peoples. These enquests often implied the assimilation of the artistictraditions of the subjugated peoples. With Mfon Njoya, we witnessed a sort of "artistic renaissance", since he was a true patron of the arts and the dynamics that he instilled in this activity in his kingdom. During his reign, liberalisation took place and many craftsmen were gathered in a street in Foumban to produce objects for which theking alone was responsible. Therefore, the Mfon no longer needed to surround himself with artists, for whom hereserved the exclusivity of the most carefully executed and most attractive decorativeworks. In addition, some of these artistic works were destined for lineage chiefs and for secret societies where they had a ritual and utilitarian function. An examination of the significance of zoomorphic decorative motifs in this cultural universe tends to show that in the "demo-anthropological" objects preserved in the palace and in the lineages, lizards were meant for princes and toads for the sons of lineage chiefs. These two batrachians thus were the symbols of fecundity, which tells how much the perpetuation of descendants is important to the bamum society. Ram heads were associated with the titamfons /, 'grand officers of the palace', while buffalo heads were reserved for the rest of palace servants. These two elements symbolise strength and combativeness, qualities that are highly sought after among this people who, at a point in time, were anxious to expand or at least consolidate their achievements.

Over time, innovations enhanced the production of works of art for commercial use, primarily intended for regional and international clients who come right to Foumban for supplies. All these transformations fostered 
Volume 9 Issue 6 June 2021

by Mfon Njoya and which gave rise to new works and allowed the development of a new market made C. TARDITS (2004) describe the history of art in the bamum land as "unique". Because of these varied productions that are more oriented towards commercialisation, contemporary bamum art marks a clear break with the "court art" that existed until the end of the 19th century.

\section{Pre-eminence of the art market over local production in Africa}

According to E. LEUZINGER (1962), colonial policy was for a very long time at the origin of an exaggerated admiration of everything foreign. She points out that missionaries fought against pagan cults in Africa and replaced them with European representations. As the 'native markets' were flooded with imports of all kinds, this dealt a fatal blow to time-consuming and unproductive handwork. However, in this new context, the black artist did find new outlets, even if they had to conform to what was required of them. According to G. BALANDIER (1972), "the negro artist of today escaped the demands of his social milieu only to submit to the demands of the colonial society."

Therefore, he has not transformed into a free creator in like manner as the emancipated man from the clan could be liberated in the colonial era. We are therefore witnessing a kind of european dirigism, according to an expression by N.M. BADI-BANGA (1977). A situation or observation that made G. BALANDIER (1972), speaking about Brazzaville, that we are witnessing in this city the "creation of a modernist art inspired by Europe and used in Europe" and P. MERCIER (1972) to add, about Dahomey, that we were almost faced with an "industrialisation of art" which henceforth give pride of place to commercial concerns. It is therefore not surprising to note that when the "indigenous handicraft" survives in a mediocre way, it owes this respite only to european clientele curious about exoticism, since it is no longer integrated into the group that generated it, and it no longer exists as a spontaneous and free creation. Apart from decorated everyday objects for personal use, "negro art", according to G. BALANDIER (1972), existed only at the request of the group, at its service and according to the forms imposed by it.

\section{African art paradox : divide between tradition and modernity}

By placing the current artistic phenomenon in vogue in its socio-historical context, J. CLIFFORD (1995) speaks of the "post-coloniality" of non-western works. This is expressed through a paradox which is that of "neo-traditionalism", which is similar to international contemporary art nourished by universalism while affirming the specificity and irreducibility of "immemorial indigenous" cultural values. We are thus witnessing a kind of fashionable multiculturalism that coexists with a heightened ethnic consciousness. C. GRAILLE (2003) speaks of an "ethnic modern" art or "new art" of non-western societies as a consecration of the "death of the authentic primitive". The works produced today in Africa undeniably mark a form of break with so-called "traditional" art in terms of the techniques and materials used as well as certain symbols evoked. The aesthetics of the works of african artists are no longer solely based on "inspiration" from the spirits or the "genius" of tradition, but are also the result of a complete technical and conceptual apprenticeship as well as regular practice guided by the search for and affirmation of a personal style, i.e. a signature. It should also be noted that the producers of traditional art lacked either creativity or artistic personality. It is simply that the western gaze, which was always looking for some primitive artistic communitarianism, obscured these latter qualities. 
Volume 9 Issue 6 June 2021

From a completely different angle, these new generations of african artists who have achieved institutional recognition, or even notoriety, because of the modernism of their work, all seem to be very concerned with maintaining a strong ethnic symbolism that is based on a certain number of references to tradition. Through this state of mind, they evoke a continuity with the past or the art of the ancients that is sometimes discreet. In fact, the modernist art in use among Africans, although it breaks with an essentialist, fixist and quasi-museographic conception of "indigenous cultures", must nevertheless be recognisable as such. This is because the artists as well as the members of the community make this art the cultural medium of the entire ethnic group. Thus, contemporary bamum artists, although in a way freed from a traditionalism considered reductive and anti-creative, are at the same time implicitly, even unconsciously, constrained not to deviate too much from an aesthetic that allows them to be more or less identified from an ethnic point of view. African artists are thus encouraged to resort to evocations and symbols of their culture of origin, although this can only limit their freedom of expression. In other words, their objects can onlyenter the emerging exhibition spaces if they conform to the canons of a contemporary "post-colonial" aesthetic, i.e. "identity", "ethnic" or "tribal". However, the conformity of nonwestern contemporary works to a certain exoticism reinforced or simply suggested by the enhancement of their hybrid character still constitutes a form of alienation from western canons of aesthetic perception. The only true liberation of the other would then consist in being able to completely "de-indigenise" his works, to rid them of all dialogue with the West and to penetrate what J.H. MARTIN (1998) calls "the bastions" of modern art. It is with this in mind that for some years now, a minority of artists have simply refused to allow their works to be perceived in terms of their ethnic origin. They claim that their aesthetic proposals are universal and no longer merely local and ethnic. It is thus a struggle for a "de-ethnicisation" of their aesthetic works that should free them from a certain form of post-colonial aesthetic orthodoxy assimilated to the tacit and solidly established cultural hybridity; even though nowadays any evacuation of ethnic references still has to be more or less justified.

\section{Principles of musealisation or patrimonialisation}

Having noted that exotic and modern western art are more or less placed on an equal footing, J. CLIFFORD (1995), spoke of a "taxonomic moment" that reflects the shift from an "artefact" classification to that of "work of art". This phenomenon owes nothing to any objective change in the quality of the objects themselves, but stems solely from a change in the way these objects are viewed. More precisely, it is a critical moment of aesthetic elaboration that consecrates the elevation of objects to the rank of work of art and their institutional redefinition through the creation of new categories of aesthetic appreciation that are now firmly established, such as "negro art", "primitive art" or "tribal art".

In order to illustrate the socially constructed character of these notions, S. ERRINGTON (1998) used a metaphor. The notion of art, she explains, is used as a bag in which the custodians of "good taste", i.e., the legitimate authorities such as collectors, art dealers, etc., store objects of their choice. Once institutionalised through museums, galleries and publications, these categories are articulated around certain aesthetic "canons" that are supposed to define the limit between the true (the authentic) and the false. Thus, through the performative discourse of the "social magic" referred to by P. BOURDIEU (1992), the exotic object acquires or does not acquire the status of a work of art and is thus "transfigured". 
The deconstruction of such a process of aestheticisation allows for a better understanding of the question of authenticity of african art. By underlining the elasticity of this concept as well as that of its corollary, the notion of "fake", the primitivist orthodoxy initially defines authentic primitive art has being produced by an indigenous person in pre-colonial technical conditions, for the sacred or profane use of his or her community alone and not for the attention of Westerners. However, a good number of ethnographic objects collected in the colonies at the beginning of the 20th century were produced on commission not only for colonial administrators but also sometimes for scientists, including Westerners, who were speculating on the growing popular infatuation with the art of the "primitives". According to P. O'REILLY (1970), such orders constitute "forgeries", some of which were later "authenticated" through their admission into the showcases of ethnographic museums or into private collections.

\section{Kaleidoscope of some traditional technical systems from the NJOYA MONTA René collection.}

In view of the influence of primitivist orthodoxy in african artistic production, it seems interesting to proceed with a discrimination of the objects listed within a private collection in Foumban.

based on the manufacturing technique and the material used as a criterion, the following distinctions could be made between woodcarving, lost wax casting, modelling, chipping technique, basketry, hollowing, pottery, cutting and other miscellaneous techniques.

\subsection{Woodcarving}

It generally includes works carved from compact, woody material. Masks, statues, symbolic objects (false elephant tusks), panels, architectural elements (posts), seats and personal objects (boxes, sceptres) represent this category. The NJOYA MONTA René collection displays 269 objects of this type. This corresponds to a relative frequency of $74.93 \%$ in the woodcarving category and $43.31 \%$ of the overall collection.

\subsection{Modelling}

Modelling usually refers to the action of shaping an object by giving a plastic material a specific form. It can be applied to masks and statues made exclusively of mineral material (clay) we tallied 42 objects in the NJOYA MONTA René collection, which is equivalent to a relative frequency of $11.69 \%$ in the woodcarving category and $06.76 \%$ of the overall collection.

\subsection{Chipping technique}

The chipping technique most often refers to an operation consisting of giving a shape to an object by using a particular way of carving. It applies here to masks made exclusively of mineral material (stone). Two examples were identified.

\subsection{Lost wax casting}

Lost-wax casting applies broadly to any operation involving the modification of soft, yellowish, fusible animal or vegetable substances by melting and moulding under the action of heat. It is used in the manufacture of masks, statues, ornaments (bangles), personal objects (ashtrays, shoes) and geometric objects. These are mainly 
objects made of copper alloy (bronze). The total number of objects identified is 44 , half of which are statues, followed by bangles and masks. Geometric objects, ashtrays and cups are poorly represented.

On the other hand, a discrimination of the material culture through the objects presented as ethnographic allows, based on the manufacturing techniques, to make the following distinctions: basketry, hollowing, forging, pottery, cutting and miscellaneous techniques.

\section{8-1. Basketry}

It generally groups together objects woven with plant fibres or stems and which A. LEROIGOURHAN (1971) presents as a technique of assembly or entanglement by hand. It represents extremely diverse objects such as fly swatters, bags, umbrellas, baskets, bowls, / nkuka'/, seats (stool, chairs, armchair), nests, musical instruments / kpètkpèt, mbangu and sha'/, shields and hats. These are exclusively objects made of very fine plant fibres or not and of stems (bamboo). The NJOYA MONTA René collection has 73 examples, i.e. a relative frequency of $27.86 \%$ in the category of ethnographic objects.

\section{8-2. Hallowed out}

This technique commonly includes objects that are indented or have a hollow. Bowls, mortars, bottles, xylophones or jars represent them. These are objects made exclusively from plant material, mainly calabashes and in some cases wood. The number of objects identified is 30, which represents a relative frequency of $11.45 \%$ in the category of ethnographic object making techniques.

From this perspective, criteria based on the nature of the material allow us to distinguish 27 calabash objects representing bowls, bottles and jars and 3 wooden objects representing mortars and a xylophone. A large proportion of bottles and jars can also be detected in the category relating to the types represented.

\section{8-3. Forging}

It generally groups together objects made of metal and various alloys that are hot worked to make swords, arrows, spears, cutters, knives, guns, bells, axes and bangles. These mainly military objects highlight the extreme diversity of techniques used by blacksmiths. It is in this perspective that it is applied outside of simple forging, invariably through damascene, brass forging, steel forging associated with the cutting technique or even by means of the perforated. The number of objects identified is 33 , which represents a relative frequency of $12.59 \%$ in the category of ethnographic object making techniques.

\section{8-4. Pottery}

Pottery is often defined as a technique for making household vessels from processed and fired clay. It can thus be applied to the manufacture of pots, jars or tea sets. The NJOYA MONTA René collection includes 10 examples. This corresponds to a relative frequency of $0.38 \%$ in the category of ethnographic object making techniques, with a predominance of pots and jars.

\section{8-5. Cutting}

It is usually applied to any operation in which wood or other material is cut into pieces ready for use. This technique is used in the manufacture of combs, cups, pestles, ladles, looms and ritual sticks. These are 
Volume 9 Issue 6 June 2021

essentially objects made of plant material (wood) which have nevertheless been worked with sharp instruments in order to give them a specific shape. The NJOYA MONTA René collection has 17 examples, i.e. a relative frequency of $06.48 \%$ in the category of ethnographic object making techniques, with a predominance of combs.

\section{8-7. Miscellaneous techniques}

This category includes objects made from a wide variety of operations: leatherwork, carpentry, binding, sewing, threading, cutting, glasswork, beading, moulding, spinning and damascene work. They can be applied to chairs, necklaces, bangles, curtains, amulets, costumes, harps, slings, bottles, castanets, sha' /, bows and drums. These are mainly works that are difficult to classify in a specific technique and that have not been systematically classified in the previous categories. The number of objects identified is 97 , which represents a relative frequency of $37.02 \%$ in the category of ethnographic object making techniques.

\section{Conclusion}

A close examination of the artistic and economic system that is flourishing in the Bamum kingdom today, which introduces itself as 'Africa in miniature' in this field, reveals its essentially commercial vocation. This illustrates a process of transformation of material culture in the sense of adaptation to exogenous influences. All of which attests to the fact that the reflective gaze of local producers, confronted with western perception, has modified to a large extent the production system of pre-existing objects. In short, the Bamum art today is situated on the threshold of a fundamentally ideological modernity that creates an anachronistic affinity with the socalled "primitive" references.

\section{References}

[1]. C. TARDITS, L'Histoire singulière de, l'artbamoum, Paris : Afredit /Maisonneuve et Larose, coll. Patrimoine architecturale, 2004, P.46

[2]. E. LEUZINGER, Afrique : l'art des peuples noirs : Paris : Albin Michel, coll. L'art dans le monde, 1962, P.43

[3]. G. BALANDIER, «Les Conditions sociologiques de l'art noir » in l'Art nègre, Présence africaine : coll. Africain du livre, 1972, P.96

[4]. N.M BADI-BANGA, Contribution à l'étude historique de l'art plastique zaïrois moderne fin $\mathrm{XV}^{\mathrm{e}}$ siècle, Kinshasa : Malayka, coll. « Propos sur l'art », AICA /Zaïre, 1977, P.67

[5]. P. MERCIER, « Evolution de l'art dahoméen » in l'Art nègre, Présence africaine, Abidjan : coll. Club africain du livre, 1972, P.138

[6]. G. BALANDIER, «Les Conditions sociologiques de l'art noir » in l'Art nègre, Présence africaine : coll. Africain du livre, 1972, P.84

[7]. C. GRAILLE, Primitifs d'hier, artistes de demain : l'art kanak et océanien en quête d'une nouvelle légitimité, inédit, P.26

[8]. S. ERRINGTON, The Death of authentic primitive art and other tales of progress, Berkeley: University of California Press, 1998, P.52

[9]. P. BOURDIEU, Les Règles de l'art. Genèse et structure du champ littéraire, Paris : Seuil, coll. Points Essais, 1998, P.64 
[10]. P. O'REILLY, De la notion de «faux » dans les collections d'objets océaniens, journal de la société des Océanistes $26: 33-38,1970$, P.74

[11]. A. LEROI-GOURHAN, l'Homme et la matière, Paris : Albin Michel, coll. Sciences d'Aujourd'hui, 1971, P.26

\section{BIBLIOGRAPHY}

G. BALANDIER, 1972 «Les conditions sociologiques de l'art noir » in l'Art nègre, Présence africaine, Abidjan : coll. Club africain du livre.

P. BOURDIEU, 1998 Les règles de l'art. Genèse et structure du champ littéraire, Paris : Seuil, coll. Points Essais.

H. DE VANINE, 1982, «Viol et vol des cultures. Un aspect de la dégradation des termes de l'échange culturel entre les nations » in Collection Passion, Neuchâtel-Suisse: coll. Musée d'ethnogaraphie.

S. ERRINGTON, 1998, The Death of authentic primitive art and other tales of progress, Berkeley: University of California Press.

C. GRAILLE, 2003, Primitifs d'hier, artistes de demain: l'art kanak et océanien en quête d'une nouvelle légitimité.

N.M.,GRANEL, 1999, Malaise dans le patrimoine, Paris : EHESS.

J., GUILHEM, 2000, «Art primitif ou patrimoine culturel : le musée du quai Branly en. question », Ethnologies comparées, 1.

J. HAINARD, 1982, Collection passion, Neuchâtel-Suisse: coll. L'Univers de l'art.

A. LEROI-GOURHAN, 1971, L'Homme et la matière, Paris: Albin Michel coll. Sciences d'aujourd'hui.

1973, Milieu et techniques, Paris : Albin Michel, coll. Sciences d'aujourd'hui.

J., MAQUET, 1972, «Connaissance actuelle de l'art afficain » in L'Art nègre, Présence africaine, Abidjan : coll. Club africain du livre.

P. MERCIER, 1972, «Evolution de l'ạrt dahoméen » in l'Art nègre, Présence africaine, Abidjan : coll. Club africain du livre.

M.M., NCHOURUPOUO MFOUAPON, 2017, L'Art et les systèmes techniques dans l'univers culturel bamum : contribution à une approche anthropologique et esthétique du patrimoine matériel en Afrique, Thèse de doctorat en Anthropologie, Université de Yaoundé I.

P. O'REILLY, 1970 « De la notion de faux » dans les collections d'objets océaniens », journal de la société des océanistes 26: 33-38.

C. TARDITS, 2004, L'Histoire singulière de l'art bamoum, Paris: Afredit/Maisonneuve et Larose, coll. Patrimoine architectural.

A.G., LOUMPET, 2003, «Le marché de l'art africain : réflexion à propos d'un commerce inégal » in Enjeux, bulletin d'analyses géopolitiques pour l'Afrique centrale, no 13. 